\title{
Pengaruh Perendaman Telur Ikan Mas (Cyprinus carpio L.) dalam Larutan Daun Jarak Pagar (Jatropha curcas L.) terhadap Daya Tetas Telur
}

\section{Effect of Soaking of Carp (Cyprinus carpio L.) Eggs in the Jatropha (Jatropha curcas L.) Solution to Egg Hatchability}

\author{
Mahyuddin, Program Studi Pendidikan Teknologi Pertanian Fakultas Teknik \\ Universitas Negeri Makassar. Email: mahyuddin97.mu@ gmail.com \\ Husain Syam, Program Studi Pendidikan Teknologi Pertanian Fakultas Teknik, Universitas \\ Negeri Makassar. Email: husain6677@yahoo.co.id \\ Amirah Mustarin, Program Studi Pendidikan Teknologi Pertanian Fakultas Teknik, \\ Universitas Negeri Makassar. Email: amirah.mustarin@unm.ac.id
}

\begin{abstract}
ABSTRAK
Penelitian ini bertujuan untuk mengetahui pengaruh perendaman larutan daun jarak pagar (Jatropha curcas L.) terhadap daya tetas telur ikan mas (Cyprinus carpio L.). Variabel bebas (Independent variable) dalam penelitian ini adalah konsentrasi larutan daun jarak yang digunakan sedangkan variabel terikat (Devendent Variable) dalam penelitian ini adalah daya tetas telur ikan mas (Cyprinus carpio L.). Penelitian ini merupakan penelitian eksperimen kuantitatif dengan menggunakan rancangan percobaan Rancangan Acak Lengkap (RAL) yang terdiri dari empat perlakuan dan tiga kali ulangan. Perlakuan ini terdiri dari perlakuan Kontrol (0 gr/l), A (2 gr/l), B (4 gr/l) dan C (6 gr/l). Teknik analisis data yang digunakan dalam penelitian ini adalah Analisis Sidik Ragam (ANOVA). Data penelitian ini diperoleh dari hasil perhitungan telur yang menetas dan menjadi larva dalam waktu 3 hari (72 jam) setelah dilakukan perendaman larutan daun jarak pagar (Jatropha curcas L.). Hasil analisis sidik ragam daya tetas telur menyatakan bahwa semua perlakuan memberikan pengaruh nyata pada daya tetas telur. Persentase daya tetas telur tertinggi terdapat pada perlakuan B sebesar 86,6\% yaitu dengan dosis larutan $4 \mathrm{gr} / \mathrm{l}$. Hal ini menunjukkan bahwa ada pengaruh perendaman telur ikan mas (Cyprinus carpio L.) dalam larutan daun jarak pagar (Jatropha curcas L.) terhadap daya tetas telur.
\end{abstract}

Kata Kunci: daun jarak pagar, daya tetas, telur, ikan mas

\section{ABSTRACT}

This study aimed to determine the effect of immersion of Jatropha leaf solution on the hatchability of carp eggs (Cyprinus carpio L.). The independent variable in this study was the concentration of jatropha leaf solution used while the dependent variable in this study was the hatchability of carp eggs (Cyprinus carpio L.) This research was a quantitative experimental research using a Completely Randomized Design (CRD) experimental design consisting of four treatments and three replications. This treatment consisted of control treatments $(0 \mathrm{gr} / \mathrm{l}), A(2 \mathrm{gr} / \mathrm{l}), B(4 \mathrm{gr} / \mathrm{l})$ and $C(6 \mathrm{gr} / \mathrm{l})$. The data analysis technique used in this study was Analysis of Variance Analysis (ANOVA). The data of this study were 
obtained from the calculation of eggs that hatch and become larvae within 3 days (72 hours) after immersion of jatropha leaf solution (Jatropha curcas L.). The results of the analysis of the variability of hatchability of eggs stated that all treatments had a significant influence on the hatchability of eggs. The highest percentage of egg hatchability was found in treatment $B$ was $86.6 \%$ with a dose of $4 \mathrm{gr} / \mathrm{l}$ solution. This showed that there was an effect of soaking carp (Cyprinus carpio L.) in Jatropha curcas solution on egg hatchability.

Key words: jatropha leaves, hatchability, eggs, carp

\section{Latar Belakang}

Perikanan budidaya adalah suatu usaha untuk memproduksi biota (organisme) akuatik di lingkungan terkontrol sebagai upaya untuk memperoleh sebuah keuntungan. Usaha budidaya yang dimaksud adalah usaha pemeliharaan untuk memperbanyak, menumbuhkan, serta meningkatkan mutu komoditi sehingga diperoleh keuntungan (Effendi, 2004). Salah satu jenis ikan air tawar yang banyak dibudidaya di Indonesia adalah ikan mas (Cyprinus carpio $L$ ). Ikan mas memiliki beberapa kelebihan dibandingkan dengan ikan air tawar lainnya yaitu mudah dipelihara, pertumbuhannya yang cepat, mempunyai nilai ekonomis yang cukup tinggi (Setiawan dkk 2017).

Ghofur dkk., (2014) mengungkapkan bahwa salah satu hal yang menjadi penghambat dalam budidaya ikan mas (Cyprinus carpio L.) pada tahap pembenihan adalah adanya serangan hama dan penyakit, tepatnya pada proses penetasan telur. Seringkali telur-telur ikan tersebut diserang oleh mikroba jenis jamur yang dapat menyebabkan daya tetas telur menjadi rendah. Jenis jamur yang biasa menyerang telur ikan mas adalah Saprolegnia sp. Jamur ini dapat berkembangbiak didalamnya karena adanya serangan bakteri. Begitu juga dengan pemindahan telur dari wadah pemijahan ke wadah penetasan, terdapat kemungkinan ikut terbawanya parasit bersama dengan telur. Hal inilah yang menjadi penyebab daya tetas telur rendah dan rentannya ikan mas terhadap agen patogen (Sugianti, 2005).

Upaya pemberantasan dengan menggunakan bahan kimia dan obatobatan yang selama ini dilakukan belum memperoleh hasil yang memadai dan sebetulnya tidak dianjurkan. Bahan-bahan kimia yang banyak digunakan antara lain Malachite green, Methylene blue, formalin maupun betadine. Ghofur dkk, (2014) mengatakan bahwa penggunaan bahanbahan kimia dan antibiotik yang berkepanjangan dengan dosis yang kurang tepat dapat meningkatkan resistensi parasit terhadap senyawa sintetik tersebut. Selain itu, juga dapat menimbulkan bahaya terhadap lingkungan dan manusia.

Budidaya ikan intensif dengan menggunakan obat-obatan dan bahan kimia yang diberikan secara rutin dapat menghasilkan limbah yang memengaruhi kondisi kualitas air (Adeyemo, 2013). Penelitian tentang penggunaan ekstrak tanaman telah dilakukan oleh banyak peneliti yang membuktikan bahwa ekstrak tanaman dapat bersifat antibakteri, antijamur, dan dapat juga digunakan sebagai imunostimulan yang tidak menimbulkan resistensi (Saptiani et al., 2012).

Adapun alternatif yang dapat digunakan untuk mencegah telur-telur agar 
terhindar dari jamur Saprolegnia sp. yaitu dengan memanfaatkan bahan-bahan alami yang bersifat anti jamur. Salah satu tanaman tradisional yang berfungsi sebagai antimikroba adalah daun jarak pagar (Jatropha curcas). Hasil penelitian yang dilakukan oleh Nuria dkk., (2009) menemukan bahwa daun jarak pagar (Jatropha curcas L.) berfungsi sebagai antimikroba terhadap bakteri Staphylococcus aureus, sehingga diduga daun jarak pagar juga dapat digunakan sebagai antimikroba untuk jamur Saprolegnia sp.

Syamsuhidayat (2000) menyatakan bahwa dalam daun jarak pagar terdapat senyawa metabolit sekunder yang aktif. Hal ini juga dibuktikan melalui penelitian yang dilakukan oleh Sharma dkk., (2012) bahwa dalam daun jarak pagar (Jatropha curcas L.) mengandung saponin, tanin, terpenoid, zat-zat alkaloid, steroid, glikosida, senyawa fenol dan flavonoid. Menurut Vijayalakshmi, et al. (2011) bahwa senyawa flavonoid dan tanin telah terbukti dapat menghambat, merusak membran sitoplasma dan menginaktivasi pertumbuhan enzim dan fungsi materi genetik jamur.

Berdasarkan uraian latar belakang di atas, maka perlu dilakukan penelitian tentang pengaruh perendaman telur ikan mas (Cyprinus carpio L.) terhadap daya tetas telur. Penelitian ini diharapkan dapat menjadi sebuah solusi bagi para pembudidaya untuk meningkatkan daya tetas telur dalam usaha budidaya ikan air tawar, khususnya ikan mas (Cyprinus carpio L.).

\section{Tujuan Penelitian}

Tujuan yang ingin dicapai dalam penelitian ini adalah:
1. Untuk menganalisis pengaruh perendaman larutan daun jarak pagar terhadap daya tetas telur ikan mas (Cyprinus carpio L.)

2. Untuk menganalisis konsentrasi yang terbaik dari larutan daun jarak pagar yang dapat meningkatkan daya tetas telur ikan mas (Cyprinus carpio L.).

\section{Bahan dan Metode}

Metode yang digunakan pada penelitian ini adalah penelitian eksperimen kuantitatif, dengan menggunakan rancangan percobaan Rancangan Acak lengkap (RAL).

\section{Waktu}

Penelitian ini dilakukan pada bulan Juli 2019. Penelitian ini dilakukan selama 2 pekan dengan persiapan penelitian meliputi pembuatan bahan larutan, persiapan indukan, proses pemijahan dan keperluan pengambilan data.

\section{Tempat}

UPTD Balai Benih Ikan Air Tawar (BBIAT) Bontomanai, Kecamatan Bontomanurung, Kabupaten Gowa, Sulawesi Selatan.

\footnotetext{
Alat dan Bahan

Alat dalam penelitian ini adalah wadah perendaman, kolam pemijahan, kakaban, baskom, aerator, $\mathrm{pH}$ meter, DO meter, thermometer, jarum suntik, timbangan, gunting dan saringan. Sedangkan bahan yang digunakan dalam penelitian ini antara lain ikan mas, hormon ovaprim, daun jarak, aquades dan air bersih.
} 


\section{Prosedur Penelitian}

1. Prosedur pembuatan larutan daun jarak pagar (Jatropha curcas L.) merujuk pada prosedur pembuatan larutan pada penelitian yang dilakukan oleh Hasan dkk, (2016) yaitu sebagai berikut:

a. Pembuatan larutan daun jarak pagar dilakukan dengan cara memilih daun jarak pagar yang masih segar.

b. Kemudian daun dibersihkan menggunakan air bersih dan ditiriskan pada suhu ruang lalu dikeringkan di bawah cahaya matahari.

c. Setelah kering, daun dihaluskan dan diayak menggunakan saringan sampai didapatkan bubuk yang agak halus.

d. Selanjutnya bubuk daun jarak pagar ditimbang dan dilarutkan dalam air pada wadah penetasan sesuai dengan perlakuan kontrol (0 g/l), A (2g/l), B (4 g/l), dan C $(6 \mathrm{~g} / \mathrm{l})$ dengan menggunakan air bersih yang telah didihkan

e. Setelah itu larutan didiamkan sampai dingin lalu dilakukan perendaman.

2. Prosedur perendaman telur

a. Setelah dilakukan proses pemijahan induk ikan mas, selanjutnya dilakukan seleksi telur-telur yang berhasil terbuahi.

b. Telur-telur yang telah terbuahi dihitung sebanyak 240 butir secara manual untuk dijadikan sampel, dimana masing-masing unit perlakuan menggunakan 20 butir sampel telur. Kemudian dilakukan perendaman dengan dosis perlakuan kontrol (0 g/l), A (2g/l), B (4 g/l) dan C $(6 \mathrm{~g} / \mathrm{l})$. Masing-masing waktu perendaman setiap perlakuan selama 4 menit.

c. Setelah dilakukan perendaman, telur dipindahkan ke wadah penetasan yang berisi air bersih dengan volume 3 L yang dilengkapi dengan aerasi dan didiamkan selama kurang lebih 3 hari sampai telur tersebut menetas

d. Setelah itu telur-telur yang telah menetas dan menjadi larva dihitung dan dicatat pada semua perlakuan.

e. Data yang didapatkan kemudian dianalisis

3. Cara menghitung daya tetas telur dan lama penetasan

a. Proses penghitungan daya tetas telur dilakukan dengan cara menghitung persentase penetasan telur pada setiap unit perlakuan dengan menggunakan rumus (Murtidjo, 2001):

$$
\begin{aligned}
& \mathrm{HR}=\frac{\text { Jumlah telur menetas }}{\text { Jumlah telur ditebar }} \times 100 \% \\
& \text { HR : Hatching Rate/Daya Tetas }
\end{aligned}
$$

b. Sedangkan untuk menghitung lama penetasan yaitu dengan melakukan pengamatan telur yang menetas setiap 6 jam selama 72 jam.

4. Pengukuran Kualitas Air (Suhu, $\mathrm{pH}$ dan DO)

a. Pengukuran suhu dilakukan dengan cara mencelupkan ujung termometer ke dalam air media penetasan selama beberapa menit sampai garis merah yang terdapat pada termometer berhenti pada angka yang menunjukkan nilai suhu tersebut. Amati dan catat hasilnya.

b. Pengukuran $\mathrm{pH}$ dilakukan dengan cara mencelupkan bagian elektroda $\mathrm{pH}$ meter ke dalam air media 
penetasan, lalu amati dan tunggu sampai nilai $\mathrm{pH}$ keluar, setelah itu catat hasilnya.

c. Pengukuran DO dilakukan dengan cara mencelupkan bagian elektroda DO meter ke dalam air media penetasan, lalu amati dan tunggu sampai nilai DO keluar, setelah itu catat hasilnya.

\section{Teknik Analisis Data}

Teknik analisis data yang digunakan dalam penelitian ini yaitu analisis sidik ragam yang diolah menggunakan program IBM SPSS 21. Jika analisis menunjukkan adanya pengaruh nyata, maka dilanjutkan uji Duncan dengan taraf kepercayaan $95 \%$.

\section{Hasil dan Pembahasan}

\section{Perhitungan Daya Tetas}

Pada Gambar 1 menunjukkan adanya perbedaan daya tetas telur pada setiap perlakuan, perendaman telur dengan menggunakan larutan daun jarak pagar sebanyak $4 \mathrm{~g} / \mathrm{L}$ memperoleh daya tetas yang tertinggi yaitu $86,6 \%$, sedangkan pada penggunaan larutan daun jarak pagar sebanyak $0 \%$ memperoleh daya tetas yang sangat rendah yaitu 23,3\%. Hal ini diduga kandungan tanin yang terdapat dalam larutan daun jarak pagar yang bersifat antimikroba berperan aktif sehingga mampu melindungi telur-telur ikan mas dari serangan jamur Saprolegnia sp. yang dapat menyebabkan telur-telur gagal menetas.

Tingginya daya tetas telur ini disebabkan karena adanya kandungan senyawa metabolit sekunder seperti tanin yang terdapat dalam larutan daun jarak pagar yang memberikan perlindungan bagi telur-telur pada saat perendaman dari serangan jamur yang dapat membuat telur gagal menetas. Jenis jamur yang biasa menyerang telur ikan adalah Saprolegnia sp. Ciri jamur tampak seperti yang dinyatakan oleh Kurniawan (2012), dimana telur yang terinfeksi oleh jamur ditumbuhi oleh sekumpulan miselium jamur yang menyerupai benang-benang halus seperti kapas, selain itu telur juga berwarna putih keruh.

Pada perlakuan A dan B, daya tetas relatif meningkat. Hal ini diduga karena adanya pengaruh kandungan tanin sebagai senyawa antimikroba yang melindungi telur dari serangan jamur Saprolegnia sp. Namun pada perlakuan $\mathrm{C}$, daya tetas relatif menurun, hal ini diduga karena adanya peningkatan dosis larutan yang digunakan. Dalam larutan daun jarak pagar (Jatropha curcas L.) tidak hanya terdiri dari senyawa tanin melainkan juga terdapat senyawa lain seperti saponin. Saponin pada dasarnya juga dapat berperan sebagai senyawa antimikroba jika penggunaannya dalam dosis tertentu, namun jika dosisnya berlebihan maka dapat menjadi racun. Sebagaimana pendapat yang dikemukakan oleh Inaya et al., (2015) bahwa senyawa saponin dapat menghambat perkembangan telur dengan cara mendegradasi dinding sel telur sehingga terjadi perubahan struktur dinding sel telur yang mengakibatkan dehidrasi sel sehingga cairan di dalam sel telur keluar. Dehidrasi sel yang terjadi akan membuat telur tidak berhasil menetas, karena dalam proses perkembangan telur memerlukan nutrisi berupa cairan sel. 


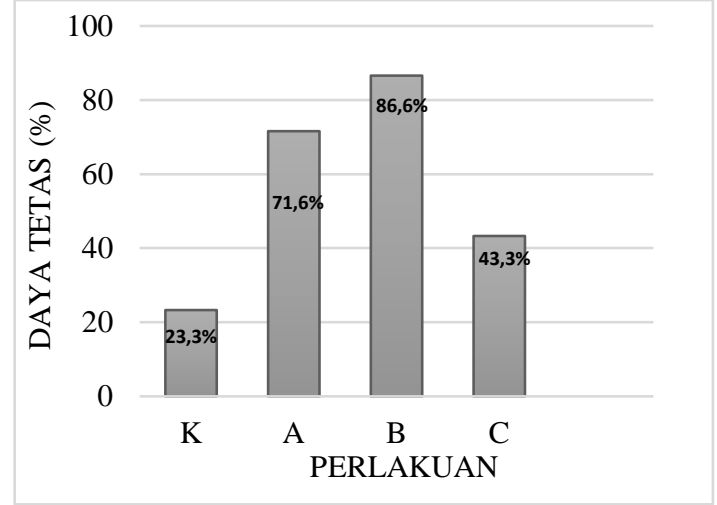

Gambar 1. Nilai Rata-Rata Daya Tetas

Telur berdasarkan Perlakuannya

Hasil Analisis Sidik Ragam daya tetas telur (Tabel 1) menunjukkan bahwa semua perlakuan memberikan pengaruh nyata pada daya tetas telur, dimana F_Hitung > F_tabel baik pada taraf 5\% $(8,709>0,304)$ maupun $1 \%(8,709>0,176)$ pada tingkat kepercayaan $95 \%$, sehingga dalam hal ini dilakukan Uji lanjut menggunakan uji Duncan.

Berasarkan hasil uji Duncan, menunjukkan bahwa perlakuan kontrol atau telur yang tidak direndam dalam larutan daun jarak pagar (Jatropha curcas L.) berbeda nyata dengan perlakuan lainnya. Perlakuan Kontrol (0 gr/l), A (2 gr/l), B (4 gr/l) dan C (6 gr/l) masingmasing memiliki perbedaan yang nyata.

Tabel 1. Analisis Sidik ragam

\begin{tabular}{|l|c|c|c|c|c|c|}
\hline \multicolumn{1}{c|}{ SK } & dB & JK & KT & F Hit & \multicolumn{2}{c|}{ F Tabel } \\
\hline & & & & & $5 \%$ & $1 \%$ \\
\hline Perlakuan & 3 & 7239.583 & 2413.194 & $8.709^{* *}$ & 0.304 & 0.176 \\
\hline Galat & 8 & 2216.667 & 277.083 & & & \\
\hline Total & 12 & 47425.000 & & & & \\
\hline
\end{tabular}

Sumber: Hasil Penelitian, 2019

\section{Pengukuran Kualitas Air}

Berdasarkan hasil yang diperoleh dari kegiatan pengamatan kualitas air selama proses penetasan telur, menghasilkan nilai kualitas air yang berbeda berdasarkan parameter. Parameter tersebut antara lain suhu, $\mathrm{pH}$ dan DO. Nilai kualitas air media penetasan selama proses penelitian dapat dilihat pada Tabel 2.

Tabel 2. Nilai Rata-Rata Perhitungan Kualitas Air

\begin{tabular}{|c|c|c|c|c|c|}
\hline \multirow{2}{*}{ No } & \multirow{2}{*}{ Perlakuan } & \multicolumn{2}{|c|}{ Suhu Air $\left({ }^{\circ} \mathbf{C}\right)$} & \multirow{2}{*}{ pH } & \multirow{2}{*}{$\begin{array}{c}\text { DO } \\
(\mathbf{m g} / \mathbf{l})\end{array}$} \\
\cline { 3 - 5 } & & Pagi & Sore & & \\
\hline 1 & $\mathrm{~K}$ & 23,3 & 26,3 & 8,4 & 5,3 \\
\hline 2 & $\mathrm{~A}$ & 23,3 & 26,3 & 8,6 & 5,2 \\
\hline 3 & $\mathrm{~B}$ & 23,3 & 26,3 & 8,5 & 5,1 \\
\hline 4 & $\mathrm{C}$ & 23,3 & 26,3 & 8,5 & 5,0 \\
\hline
\end{tabular}

Sumber: Hasil Penelitian, 2019

Gusrina (2008) menyatakan bahwa faktor eksternal yang mempengaruhi penetasan telur ikan antara lain suhu, $\mathrm{pH}$, oksigen dan intensitas cahaya. Proses perkembangan embrio umumnya berlangsung lebih cepat pada suhu yang lebih tinggi dibandingkan pada suhu rendah. Hal ini dikarenakan pada suhu yang tinggi proses metabolisme embrio berjalan lebih cepat sehingga perkembangannya juga cepat. Sehingga pergerakan embrio dalam cangkang menjadi lebih intensif.

Oksigen terlarut (dissolved oxygen) adalah salah satu parameter kualitas air yang berpengaruh dalam kegiatan akuakultur, baik pada tahap pembenihan maupun pembesaran. Ketersediaan oksigen terlarut dalam media budidaya akuakultur menjadi salah satu faktor keberhasilan budidaya (Wahab, et al., 2019). Hasil pengukuran DO (dissolved oxygen) menunjukkan bahwa nilai oksigen terlarut pada media penetasan berada pada kisaran 5-5,3 mg/L. Kisaran DO tersebut terbilang berada pada kisaran normal. Hal ini didukung oleh pendapat dari Sunarma (2004) bahwa DO optimum yaitu di atas 1 ppm. Oksigen terlarut ini berasal dari aerasi yang terpasang dalam wadah 
penetasan. Herianto, et al., (2019) menyatakan bahwa aerasi berfungsi untuk menyuplai oksigen masuk ke dalam air sehingga konsentrasi oksigen dalam air dapat terpenuhi.

Hasil pengukuran $\mathrm{pH}$ pada media penetasan yaitu nilai $\mathrm{pH}$ berada pada kisaran 8,4-8,6. Nilai $\mathrm{pH}$ tersebut masih terbilang normal, dimana Sunarma (2004) menyatakan bahwa kisaran $\mathrm{pH}$ optimum yaitu 6-9.

Dari hasil pengukuran suhu pada media penetasan, rata-rata suhu berada pada kisaran $23,3^{\circ} \mathrm{C}-26,3^{\circ} \mathrm{C}$. Sunarma (2004) meyatakan bahwa kisaran suhu normal untuk penetasan telur adalah $22^{\circ}$ $34^{\circ} \mathrm{C}$. Sehingga dapat dipastikan bahwa suhu pada media penetasan terbilang normal. Perbedaan suhu pada pagi hari dan sore hari disebabkan oleh beberapa faktor diantaranya karena adanya perbedaan waktu pengamatan dan kedalaman air yang diukur (Alfionita, et al., 2019).

\section{Lama Penetasan}

Proses pengamatan lama penetasan telur ikan mas (Cyprinus carpio L.) dapat dilihat pada Tabel 3, menunjukkan bahwa perlakuan yang paling cepat membuat telur menetas adalah perlakuan C (dengan dosis perendaman larutan daun jarak pagar sebanyak $6 \mathrm{~g} / \mathrm{L}$ ) dimana telur menetas pada hari kedua atau 42 jam setelah perendaman meskipun jumlah telur yang menetas selama proses penetasannya terbilang lebih rendah dibanding perlakuan yang lainnya yaitu totalnya 16 telur dari tiga kali ulangan. Selanjutnya menyusul perlakuan B (dengan dosis perendaman larutan daun jarak pagar sebanyak $4 \mathrm{~g} / \mathrm{L}$ ) dan kontrol (dengan dosis perendaman larutan daun jarak pagar sebanyak $0 \mathrm{~g} / \mathrm{L}$ ) dengan masing-masing jumlah telur yang menetas sebanyak 2 butir pada jam ke-48 setelah dilakukan perendaman. Pada jam yang sama di perlakuan $C$ juga kembali menetas sebanyak 3 butir telur. Puncak tertinggi terjadinya proses penetasan pada setiap perlakuan terjadi pada jam ke-54 setelah perendaman, dimana jumlah penetasan penetasan tertinggi terdapat pada perlakuan B, kemudian perlakuan A, $\mathrm{C}$ dan kontrol.

Tabel 3. Data Pengamatan Lama Penetasan

\begin{tabular}{|c|c|c|c|c|c|c|c|c|c|c|c|c|c|c|}
\hline \multirow{2}{*}{ No } & \multirow{2}{*}{ perlakuan } & \multicolumn{12}{|c|}{ Jumlah telur menetas setiap 6 jam selama 72 jam } & \multirow{2}{*}{ Total } \\
\hline & & 6 & 12 & 18 & 24 & 30 & 36 & 42 & 48 & 54 & 60 & 66 & 72 & \\
\hline 1 & $\mathrm{~K} 1$ & - & - & - & - & - & - & - & - & - & - & - & - & $\mathbf{0}$ \\
\hline 2 & $\mathrm{~K} 2$ & - & - & - & - & - & - & - & 1 & 3 & - & - & 1 & 5 \\
\hline 3 & $\mathrm{~K} 3$ & - & - & - & - & - & - & - & 1 & 7 & - & - & 1 & 9 \\
\hline 4 & A1 & - & - & - & - & - & - & - & 1 & 14 & - & 1 & - & 16 \\
\hline 5 & $\mathrm{~A} 2$ & - & - & - & - & - & - & - & - & 7 & 8 & - & - & 15 \\
\hline 6 & $\mathrm{~A} 3$ & - & - & - & - & - & - & - & - & 11 & 1 & 1 & - & 12 \\
\hline 7 & B1 & - & - & - & - & - & - & - & 2 & 9 & 2 & - & 1 & 14 \\
\hline 8 & B2 & - & - & - & - & - & - & - & - & 12 & 7 & - & 1 & 20 \\
\hline 9 & B3 & - & - & - & - & - & - & - & - & 18 & - & - & - & 18 \\
\hline 10 & $\mathrm{C} 1$ & - & - & - & - & - & - & 1 & 2 & 7 & 1 & - & - & 11 \\
\hline 11 & $\mathrm{C} 2$ & - & - & - & - & - & - & - & 1 & 7 & 1 & - & 1 & 10 \\
\hline 12 & C3 & - & - & - & - & - & - & - & - & 5 & - & - & - & 5 \\
\hline
\end{tabular}

Sumber: Hasil Penelitian, 2019

Hubungan antara dosis larutan perendaman dengan kecepatan tetas telur adalah semakin tinggi dosis larutan maka akan semakin cepat terjadinya penetasan. Hal ini dikarenakan semakin tinggi dosis larutan yang digunakan maka kandungan saponinnya juga semakin tinggi. Kandungan saponin yang tinggi dapat mendegradasi membran atau dinding sel telur sehingga larva dalam telur tersebut cepat keluar. Hal ini sesuai dengan pernyataan Inaya et al., (2015) bahwa senyawa saponin dapat menghambat perkembangan telur dengan cara mendegradasi dinding sel telur sehingga terjadi perubahan struktur dinding sel telur yang mengakibatkan dehidrasi sel sehingga cairan di dalam sel telur keluar. Namun disisi lain hal ini juga dapat 
berpotensi mengakibatkan telur mati saat sel yang terdapat dalam telur belum terbentuk secara sempurna dan belum siap untuk menetas.

Faktor lain yang berpengaruh terhadap kecepatan tetas telur adalah faktor kualitas air yaitu suhu. Suhu yang tinggi akan menyebabkan embrio menetas secara prematur sedangkan suhu rendah menyebabkan embrio akan lebih lama tertahan dalam cangkangnya, namun pada umumnya larva tidak akan mampu bertahan hidup lebih lama (Effendi, 2009). Namun dari hasil penelitian, kisaran suhu setiap perlakuan terbilang sama akan tetapi kecepatan tetasnya berbeda-beda. Maka dapat disimpulkan bahwa pada penelitian ini suhu tidak berpengaruh secara signifikan terhadap kecepatan tetas telur.

\section{Simpulan}

Berdasarkan hasil pembahasan dalam penelitian ini, maka dapat disimpulkan sebagai berikut:

1. Terdapat pengaruh proses perendaman larutan daun jarak pagar (Jatropha curcas L.) terhadap daya tetas telur ikan mas (Cyprinus carpio L.), dari hasil perhitungan daya tetas telur, masing-masing perlakuan memiliki perbedaan yang nyata.

2. Konsentrasi terbaik larutan daun jarak pagar (Jatropha curcas L.) dengan tingkat daya tetas telur ikan mas (Cyprinus carpio L.) tertinggi adalah pada perlakuan B (dengan dosis $4 \mathrm{~g} / \mathrm{L}$ ) dimana jumlah daya tetas sebesar $86,6 \%$.

\section{Daftar Pustaka}

Adeyemo A., O. 2013. Effective Fish Health Management Strategy in Nigeria: A Review. Int J of Plant and Animal Sci. Vol. 1 (1): 1-4.

Alfionita, A., N., A., Patang dan Kaseng, E.S. 2019. Pengaruh Eutrofikasi Terhadap Kualitas Air di Sungai Jeneberang. Junal Pendidikan Teknologi Pertanian. Vol. 5 (1): 9-23

Effendi, I. 2004. Pengantar Akuakultur. Jakarta: Penebar Swadaya.

Ghufron. M. H. K. 2010. Marikultur Prinsip dan Praktek Budidaya Laut. Yogyakarta: Andi.

Ghofur, M., Sugihartono, M. dan Thomas, R. 2014. Efektivitas Pemberian Ekstrak Daun Sirih (Piper betle L.) Terhadap Penetasan Telur Ikan Gurami (Osphronemus gouramy. Lac). Jurnal Ilmiah Universitas Batanghari Jambi. Vol. 14 (1): 37-44.

Gusrina. 2008. Budidaya Ikan Jilid 2. Direktorat Pembinaan Sekolah Menengah Kejuruan Direktorat Jenderal Manajemen Pendidikan Dasar dan Menengah Departemen Pendidikan Nasional. Jakarta.

Hasan, H., Raharj, E. I. dan Ariyanti, D. D. 2016. Pengaruh Ekstrak Daun Kemangi (Ocimum Basilicum L) Terhadap Daya Tetas Telur Ikan Lele Dumbo (Clarias Gariepinus) yang Diinfeksi Jamur Saprolegnia Sp. Jurnal Ruaya. Vol. 4(1): 18-23.

Herianto, Amirah dan Patang. 2019. Pengaruh Penambahan Tepung Daun 
Singkong (Manihot Utillisima) pada

Pendederan Ikan Lele Dumbo (Clarias Gariepinus) Untuk Meningkatkan Pertumbuhan Dan Sintasan. Jurnal Pendidikan Teknologi Pertanian. Vol. 5 Suplemen 2019: S169 - S182.

Inaya A., Kismiyati F. N. dan Subekti, S. 2015. Pengaruh Perasan Biji Pepaya (Carica papaya) Terhadap Kerusakan Telur Argulus Japonicus. Jurnal Ilmiah Perikanan dan Kelautan. Vol. 7(2): 159-164.

Murtidjo, B., A. 2001. Beberapa Metode Pembenihan Ikan Air Tawar. Yogyakarta: Kanisus.

Nuria, M.,C, Arvin Faizatun, dan Sumantri. 2009. Uji Aktivitas Antibakteri Ekstrak Etanol Daun Jarak Pagar (Jatropha curcas L.) Terhadap Bakteri Staphylococcus aureus, Escherechia coli dan Salmonela typhi. Jurnal Ilmu-ilmu Pertanian. Vol. 5 (2): 10-12.

Saptiani G, Prayitno SB, Anggoro S. 2012. Aktivitas Antibakteri Ekstrak Jeruju (Acanthus ilicifolius) terhadap Pertumbuhan Vibrio harveyi Secara in vitro. Jurnal Veteriner Vol. 13 (3): 257-262.

Setiawan, H., Madusari, B., D. dan Syakirin, M., B. 2017. Pengaruh Berbagai Dosis Perendaman Ekstrak Daun Cengkeh Terhadap Daya Tetas Telur Ikan Mas (Cyprinus Carpio L.). PENA Akuatika. Vol. 15 (1): 31-40.

Sharma, A.K., Gangwar, M., Tilak, R., Nath, G., Sinha, A.S.K., Tripathi,
Y.B. dan Kumar, D. 2012. Comparative in Vitro Antimicrobial and Phytochemical Evaluation of Methanolic Extract of Root, Stem and Leaf of Jatropha curcas Linn. Journal of Pharmacognosy. Vol. 4 (30): 3440.

Sugianti, B. 2005. Pemanfaatan Tumbuhan Obat Tradisional dalam Pengendalian Penyakit Ikan. Makalah Pribadi Falsafah Sains. Sekolah Pasca Sarjana. Institut Pertanian Bogor.

Sunarma, A. 2004. Peningkatan Produktifitas Usaha Lele Sangkuriang (Clarias sp.). Departemen Kelautan dan Perikanan. Direktorat Jenderal Perikanan Budidaya. Balai Budidaya Air Tawar Sukabumi. Sukabumi. Hal. 1- 6 .

Syamsuhidayat. 2000. Inventaris Tanaman Obat Indonesia. Jakarta: Departemen Kesehatan RI dan Kesejahteraan Sosial.

Vijayalakshmi, A., Tripura, A., and Ravichandiran, Y. 2011. Development and Evaluation of Anti-acme Products From Terminalia anjuna Hark. International Journal of Chem Tech Research. Vol. 3 (1): 320-327.

Wahab, M.I.A., Patang dan Nurmila. 2019. Modifikasi Aerasi terhadap Peningkatan Oksigen Terlarut yang Mempengaruhi Tingkat Pertumbuhan dan Sintasan pada Ikan Nila (Oreochrobis Niloticus). Jurnal Pendidikan Teknologi Pertanian. Vol. 2 (2): 65-72. 
Halaman ini sengaja dikosongkan 